\title{
ENSINO DE QUÍMICA: AS DIFICULDADES E DESAFIOS DE PROFESSORES EM ESCOLAS DA REDE PÚBLICA
}

\section{CHEMISTRY TEACHING: THE DIFFICULTIES AND CHALLENGES OF TEACHERS IN SCHOOLS OF THE PUBLIC NETWORK}

\author{
Josivaldo Miguel Matias$^{1}$; Kilma da Silva Lima Viana²
}

\section{INTRODUÇÃO}

A Educação brasileira passa por problemas estruturais nos mais diversos aspectos. Quando voltamos o nosso olhar para o chão da escola e, especificamente, para o cotidiano das salas de aulas de Química, esses problemas são gritantes. Diante disso, o presente trabalho teve o objetivo de analisar o cotidiano da sala de aula de Química, de uma instituição de ensino da Rede Estadual, na cidade de Pombos-PE. A pesquisa teve uma abordagem qualitativa e teve como sujeitos os professores da referida escola. Na pesquisa, foram observadas a carga horário do professor, formas de abordagem, relação do professor com os estudantes e com o conhecimento abordado. Espera-se, com os resultados de nossa pesquisa, contribuir para a discussão do ensino de Química.

\section{FUNDAMENTAÇÃO TEÓRICA}

O ensino de Química, historicamente, apresenta uma perspectiva que está relacionada à uma abordagem tradicional (MIZUKAMI, 1986), com aulas expositivas e estudantes passivos, tendo o professor como o detentor do conhecimento que trata o conhecimento como algo pronto e acabado.

Essa visão, segundo pesquisa de Viana (2014) retrata uma realidade que traduz uma fragilidade no processo de formação dos professores dessa área. Diante disso, Viana (2014) afirma que os cursos de licenciatura acabam por sofrer impacto tanto das questões específicas da Química, quanto dos aspectos pedagógicos, pois, devido a diversos fatores, inclusive de ordem social, as licenciaturas não apresentam tempo pedagógico suficiente para o aprofundamento necessário para a formação dos professores. Em consequência, esses professores acabam por priorizar os aspectos específicos em detrimento dos pedagógicos. Assim, os estudos acerca de novas propostas pedagógicas ficam em segundo plano, fazendo com que as aulas tomem uma configuração de abordagem tradicional.

Arruda et al (2016) ressalta que existem também fatores que dificultam a mudança dessa

\footnotetext{
${ }^{1}$ Licenciando em Química, IFPE, josivaldomiguel05@gmail.com

2 Doutora em Ensino de Ciências, Líder do Grupo de Pesquisa GEPEC, IFPE, kilma.viana@vitoria.ifpe.edu.br
} 

realidade nas escolas, entre elas é a falta de valorização do magistério, fazendo com que os jovens não considerem como opção essa carreira. Com poucos professores nas escolas, muitos profissionais que ministram o componente curricular de Química não tenham formação específica na área. Muitos são formados em Biologia, Física, Engenharia. Outro aspecto destacado por Arruda et al (2016) são os baixos salários e péssimas condições de trabalho. Diante disso, faz-se necessária a realização de pesquisas na área, na perspectiva de superação dessa realidade.

\section{METODOLOGIA}

A pesquisa em tela teve uma natureza qualitativa, pois não teve a intenção de analisar resultados numericamente relevantes, mas sim, compreender os aspectos subjetivos dos dados coletados para a compreensão do fenômeno estudado. O campo de pesquisa foi uma escola da Rede Pública do município de Pombos, do estado de Pernambuco. Os sujeitos de pesquisa foram professores dessa instituição que ministram aulas do componente curricular Química no Ensino Médio.

Para o alcance do objetivo da pesquisa, foi feita uma análise a respeito das condições em que a instituição se encontrava, com foco na área de Química. Observamos também os espaços físicos disponíveis e as condições de trabalho e o mais importante: como é lecionado a disciplina de Química, tendo como foco o docente. Para isso, foi feito o acompanhamento de suas aulas, onde foram feitos observações e registros.

\section{RESULTADOS E DISCUSSÃO}

A nossa pesquisa ocorreu através de visitas a instituição de ensino supracitada. Observamos um cenário com diversos problemas. Uma realidade, de fato, preocupante. Observamos professores sem formação na área, mas que lecionam a disciplina apenas para complementar sua carga horária. Professores que não apresentam bom relacionamento com seus estudantes e que, muitas vezes, não parecem estar preocupados com a aprendizagem dos estudantes. Foi observado também professores que, por não terem formação na área, não dominam o componente curricular. São professores de Biologia que lecionam Química, professores de Química que lecionam a Física. Ou seja, numa mesma escola, professores desviados das suas áreas, mesmo tendo sua vaga ocupado por um profissional que não tem formação. Consideramos este aspecto um dos mais preocupantes em nossa pesquisa.

Segundo (Souza 2012), esses problemas estão atribuídos ao caráter financeiro, cultural e também a não continuação da formação destes professionais. Assim, Souza (2012) destaca 
que a condição em que o professor está inserido tanto na questão financeira, quanto em todo contexto social, influencia como esse docente irá trabalhar com seus estudantes, pois dificilmente alguém passando problemas, por exemplo: condições de trabalho ou financeiros, irá conseguir proporcionar uma aula tão boa quanto alguém que não esteja passando por tais problemas.

Analisando a situação que os professores vivenciam cotidianamente nessa instituição, foi possível elencar que as condições de trabalho não são adequadas, a escola não dispõe de estrutura física que propicie um ambiente de aprendizagem satisfatório. Os professores não demonstram prazer no que fazem e sua relação com os estudantes não são boas, no sentido de que não conseguem promover aulas interativa, em que o estudante demonstre entusiasmo.

Nessa perspectiva, têm-se as seguintes hipóteses de como poderia estar resolvendo estes problemas: primeiro, os gestores das instituições precisariam evitar o desvio de professores para outras áreas, pois isso acarreta prejuízo tanto na aprendizagem do estudante, quanto também na satisfação do professor em fazer a diferença dentro dessa realidade. Segundo, a questão das condições de trabalho, que causa tanto desestímulo aos docentes, poderia ser resolvido se o governo fizesse mais investimentos na educação, por exemplo, que buscasse formas de melhorar a estrutura e as condições para todos os profissionais da área, com melhores salários, melhoria no plano de carreira e também condições físicas das instituições, que hoje grande parte delas se encontram em estado de abandono.

É sabido que resolver essas questões não é algo fácil, nem é algo que possa ser pensado de forma linear. É muito mais complexo do que uma análise em primeiro momento demonstra. Mas é preciso começar a mudar o que se pode mudar, o que não se pode é deixar sempre mais do mesmo, sempre, ano após ano, pesquisa após pesquisa, concluir que não houve mudança.

Diante de nossa pesquisa compreendemos que o professor que está lá na ponta desses problemas pede socorro. A forma que faz isso é expondo sua insatisfação e, muitas vezes, realizando aulas sem encantamento. Mas, pesquisas indicam que o professor é idealista, ele sonha com uma Educação de qualidade, ele deseja que seus estudantes aprendam e cresçam e, apesar dos dados coletados nessa pesquisa terem sido negativos, foi um recorte de uma realidade que, a cada dia, sabemos que precisa ser mudada

\section{CONSIDERAÇÕES}

A presente pesquisa, bem como, as vivências experimentadas na instituição, contribuíram, significativamente, para nossa formação. Diante dos dias de acompanhamento das aulas que pudemos presenciar, com um olhar mais crítico, no que se refere a nossa condição 
de licenciando, podemos afirmar que ampliou nossa visão quanto ao modo de ser e não ser um educador. Isso nos remete à realidade que vamos encontrar após a conclusão do curso e a certeza de que não é nada fácil, mas que este desafio nos motiva a querer mudar esta realidade.

Os pontos negativos encontrados e abordados aqui, deixa bastante claro a defasagem do ensino de Química, e o resultado disso é um déficit muito acentuado dos alunos no aprendizado e compreensão dos assuntos abordados. Historicamente, a disciplina de Química já é vista como ciência de difícil entendimento e atrelado a isso ainda ter professores que não estão preparados para lecionar o componente curricular, que não sabe fazer uma aula diferente da expositiva, que não sabe realizar um experimento, não busca outras maneiras de melhor atrair o olhar diferente de seus estudantes, tem como consequência ainda mais impactos negativos na aprendizagem do estudante.

\section{REFERÊNCIAS}

ARRUDA, C. A. et al. Avaliação da Aprendizagem no Ensino de Cinética Química. In: I Simposio Latinoamericano em Formación de Profesores: Tecnología y Educación,. Anais do I Simposio Latinoamericano em Formación de Profesores: Tecnología y Educación, Playa Ancha, Valparaiso, 2016.

LIMA, K. S. Compreendendo as concepções de avaliação de professores de física através da Teoria dos Construtos Pessoais. Recife, 2008. 163f. Dissertação (Ensino das Ciências). Departamento de Educação, Universidade Federal Rural de Pernambuco - UFRPE, Recife, 2008.

MIZUKAMI, M. G. M., Ensino: As abordagens do processo. São Paulo: Editora Pedagógica e Universitária (EPU), 1986.

SOUZA, A. R. O professor da educação básica no Brasil: identidade e trabalho. $E d u c$. rev. [online]. 2013, n.48, pp.53-74. ISSN 0104-4060. http://dx.doi.org/10.1590/S0104$\underline{40602013000200005 .}$.

VIANA, K. S. L. Avaliação da Experiência: uma nova perspectiva de Avaliação para o ensino das Ciências da Natureza. Recife, 2014. 202f. Tese (Ensino de Ciências e Matemática Modalidade Física e Química) - Departamento de Educação, Universidade Federal Rural de Pernambuco - UFRPE, Recife, 2014. 